\title{
Triple Test Cross Analysis for Yield and Horticultural Traits in Brinjal (Solanum melongena L.)
}

\author{
Smita Kumari*, K.S. Chandel and Aanchal Chauhan \\ Department of Vegetable Science and Floriculture, CSKHPKV, Palampur (H.P.), India
}

*Corresponding author

\section{A B S T R A C T}

\begin{tabular}{|l|}
\hline K e y w o r d s \\
Brinjal, \\
Triple test cross, \\
Epistasis, \\
Additive and \\
Dominance \\
component. \\
\hline Article Info \\
\hline Accepted: \\
26 May 2017 \\
Available Online: \\
10 June 2017 \\
\hline
\end{tabular}

Vegetable breeding generally depends on the nature and genetic components of variation. Thus it is necessary to have reliable estimates of such components in order to formulate an efficient breeding strategy. In the present study, ten diverse inbred lines were crossed to three testers viz., SP, H-8 and their F1 SP x H-8 at the Experimental Farm, Department of Vegetable Science and Floriculture, CSKHPKV, Palampur (H.P.) during kharif, 2015 to assess the nature and magnitude of genetic variability and to understand the association between different horticultural traits. Data were recorded for marketable fruit yield per plant, days to 50 per cent flowering, days to first picking, number of marketable fruits per plant, fruit length and fruit diameter. The parents (lines and testers) and their crosses were evaluated in Randomized Block Design. Analysis of variance revealed significant differences among progenies. All the characters showed significant in total epistasis. Both additive and non-additive interaction i.e., (i) type epistasis was significant for all traits except fruit length and fruit diameter whereas for $(j+1)$ type epistasis was significant for all traits except days to first picking. Degree of dominance was in the range of partial dominance. Correlation coefficient was non-significant for all traits except marketable fruit yield per plant and days to $50 \%$ flowering. Heritability (narrow sense) estimates were low to medium.

\section{Introduction}

Brinjal (Solanum melongena L.) is known as eggplant or aubergine (French word) belongs to family Solanaceae and it is also known as queen of vegetable. It is an autogamous crop adapted to wide climatic range and exhibit variation in colour, size and shape of the fruit (Hazra et al., 2011) and one of the most commonly grown vegetables all the year round in the country. India is considered to be the centre of origin of brinjal (Zeven and Zhukovsky 1975) with secondary diversity in China and South East Asia (Nath et al., 1987).
It contains enormous genetic variability which coupled with its biological diversity make it suitable for study of genetic principles which are of practical significance to plant breeders. The elucidation of genetic components of variance is an important pre-requisite for efficient management of available genetic variability and formulation of systematic breeding programme. However, the estimation of these components gets significantly biased in presence of epistasis, which leads to erroneous estimation of 
genetic parameters. TTC (Triple test cross) analysis provides unambiguous test for the presence of epistasis regardless of gene frequencies, degree of inbreeding and linkage relationships. The design has wide applicability as it can be used to investigate both segregating and non-segregating populations arising from different generations such as F2, backcross and homozygous lines. Therefore the present study was undertaken to get an insight into the genetic factors underlying expression of quantitative traits.

\section{Materials and Methods}

The material for present study was developed by crossing ten diverse inbred to three testers viz., SP, H-8 and their F1 SP x H-8 as per procedure of Kearsey and Jinks (1968). Thus the experimental material comprised of 43 genotypes including 10 lines, 3 testers and 30 test cross progenies. Each genotype was grown in three rows $3.0 \mathrm{~m}$ long.

The beds with inter and intra row spacing of $60 \mathrm{~cm}$ and $45 \mathrm{~cm}$, respectively and were sown on raised nursery beds on April 19, 2015 and transplanting was carried out on June 4, 2015 at the Experimental Farm, Department of Vegetable Science and Floriculture, CSKHPKV, Palampur (H.P.) during kharif, 2015. Data were recorded from 10 randomly selected competitive plants on ten traits viz, marketable fruit yield per plant, days to 50 per cent flowering, days to first picking, number of marketable fruits per plant, fruit length and fruit diameter. The detection of epistasis was done as per method of Ketata et al., (1976) which is based on procedure of Kearsey and Jinks (1968) and is based on the genetic model:

Lijk $=m+G i j+R$ k + Eijk

Where,
Lijk = Phenotypic value of cross between test $\mathrm{Li}$ and line $\mathrm{j}$ in Kth replication

$\mathrm{m}=$ Overall mean of all single and three way crosses.

Gij = Genotypic value of cross between tester Li and line $\mathrm{j}$.

$\mathrm{Rk}=$ Effect of Kth replication

Eijk $=$ error .

The mean squares for deviations L1 $\mathrm{i}+\mathrm{L} 2 \mathrm{i}-2$ L3i was used for detection of epistasis. The procedure of Kearsey and Jinks (1968) even though suffers from the limitation that it only detects epistasis between loci for which the testers L1 and L2 differ and there can be discrepancies due to inadequacies of testers. However, the procedure provides unambiguous test of epistasis regardless of gene frequencies, degree of inbreeding or linkage relationships.

\section{Results and Discussion}

The mean square from the analysis of variance for 6 characters in triple test cross families are presented in (Table 1). The mean squares due to parents (both lines and testers), crosses and parents $\mathrm{v} / \mathrm{s}$ crosses indicating thereby that the inbred lines used in present study were diverse and that significant differences were present in progenies for all traits. This indicated that considerable amount of genetic variability was present in the material studied and material was suitable for the study of manifestation of genetic parameters involved in the inheritance of different traits.

The mean square from the analysis of variance of triple test cross progeny families for the test of epistasis and the adequacy of testers for 6 quantitative traits are presented in Table 2. For detection of epistasis revealed 
significant overall epistasis $(\mathrm{L} 1 \mathrm{i}+\mathrm{L} 2 \mathrm{i}-2 \mathrm{~L} 3 \mathrm{i})$ for all traits. Both additive and non-additive interaction i.e., (i) type epistasis was significant for all traits except fruit length and fruit diameter whereas for $(\mathrm{j}+\mathrm{l})$ type epistasis was significant for all traits except days to first picking. Epistasis for yield and its components traits has been also reported by several recent studies conducted by Kaur and Thakur (2007), Sabolu et al., (2014), Chauhan and Chandel (2016) in brinjal.

The estimation of genetic components of variance was based on analysis of sums and differences (Table 3). Additive and dominance component was significant for all the traits. The degree of dominance was in the range of partial dominance for all days to 50 $\%$ flowering and days to first picking whereas rest of the characters showed over dominance. The similar results was finding with Dhameliya, and Dobariya (2007), Naik et al., (2009), Reddy and Patel (2014).

The directional element ' $F$ ' was positive but non-significant indicating ambidirectional nature of dominance for fruit length and fruit diameter suggesting that alleles with increasing and decreasing effects appeared to be dominant and recessive to the same extent (Table 3). A negative ' $F$ ' means dominant alleles carry negative (decreasing) effects more frequently than positive (increasing) effects and vice-versa.

Thus, in the present case negative but significant ' $F$ ' was observed for marketable fruit yield per plant $(\mathrm{g})$ and days to 50 per cent flowering, which means dominant alleles carry negative (decreasing) effects more frequently than positive (increasing) effects. It may be argued that either epistasis or dominance does not have much of directional element. Singh and Singh (2010) showed that the positive and non-significant value of $\mathrm{F}$ for plant height, number of branches per plant, number of flower per cluster, number of fruit per plant, fruit size, fruit weight and yield per plant suggested ambidirectional nature of dominance in tomato.

Narrow sense heritability is important for breeding programmes as it estimates the relative importance of the additive portion of the genetic variance that can be transmitted to the next generation.

According to Bhateria et al., (2006) the narrow sense heritability (h2ns) estimates were classified as high (>50\%), medium (30$50 \%)$ and low $(<30 \%)$. On the basis of present study, heritability estimates were low to moderate with highest value recorded for bacterial wilt incidence $(43.45 \%)$ and lowest value for marketable fruit yield per plant $(\mathrm{g})$ $(-0.43 \%)$. Low narrow sense heritability estimates that genetic variation of these traits is mainly affected by the non-additive gene effects. This indicates that selection in early hybrid generations may be successful. These are findings with Salehuzzaman (1983), Chaudhary (2001) and Dagade (2015).

Genetic architecture of any crop species has a great bearing on success of breeding procedures. Since it is already established that estimates of genetic parameters get biased in presence of epistasis, it is imperative to get a clearer picture by getting unbiased estimates of such parameters. In this context, triple test cross is a useful procedure to detect epistatic bias and is equally applicable to segregating and non-segregating generations such as F2, backcross and homozygous lines (Kearsey and Jink, 1968 and Chahal and Jinks, 1978). 
Table.1 Analysis of variance for yield and its component traits in triple test cross Progenies of brinjal - mean squares

\begin{tabular}{|l|l|l|l|l|l|l|l|}
\hline Source of variation & $\begin{array}{l}\text { Replic } \\
\text { ation }\end{array}$ & Parent & Line & Tester & Crosses & $\begin{array}{l}\text { Parent vs } \\
\text { Crosses }\end{array}$ & Error \\
\hline Traits df & $\mathbf{2}$ & $\mathbf{1 2}$ & $\mathbf{9}$ & $\mathbf{2}$ & $\mathbf{2 9}$ & $\mathbf{1}$ & $\mathbf{8 4}$ \\
\hline $\begin{array}{l}\text { Marketable fruit yield } \\
\text { per plant (g) }\end{array}$ & 24.123 & $74975.2^{* *}$ & $42142.77^{* *}$ & $14789.70^{* *}$ & $45298.05^{* *}$ & $8804.88^{* *}$ & 54.23 \\
\hline Days to 50 \% flowering & 7.837 & $110.62^{* *}$ & $120.03^{* *}$ & $110.77^{* *}$ & $98.76^{* *}$ & $12.46^{* *}$ & 3.20 \\
\hline Days to first picking & 23.171 & $134.31^{* *}$ & $137.31^{* *}$ & $175.00^{* *}$ & $110.75^{* *}$ & $12.56^{*}$ & 2.88 \\
\hline $\begin{array}{l}\text { Number of marketable } \\
\text { fruits per plant }\end{array}$ & 40.123 & $16.41^{* *}$ & $17.007^{* *}$ & $15.18^{* *}$ & $19.73^{* *}$ & $89.02^{* *}$ & 4.97 \\
\hline Fruit length $(\mathrm{cm})$ & 30.195 & $9.28^{* *}$ & $6.82^{*}$ & $16.45^{* *}$ & $12.76^{* *}$ & $45.92^{* *}$ & 2.96 \\
\hline Fruit diameter $(\mathrm{cm})$ & 0.333 & $1.55^{* *}$ & $1.26^{* *}$ & $0.66^{* *}$ & $1.932^{* *}$ & $5.56^{* *}$ & 0.34 \\
\hline
\end{tabular}

*,** Significant @ $5 \%$ and 1\% level

Table.2 Analysis of variance for detection of epistasis for yield and its component Traits in brinjal - mean squares

\begin{tabular}{|l|c|c|c|c|c|c|c|}
\hline \multicolumn{1}{|c|}{ Source of variation } & & $\begin{array}{c}\text { Epistasis } \\
\left(\mathrm{L}_{1 \mathrm{i}}+\mathrm{L}_{2 \mathrm{i}}\right. \\
2 \mathrm{~L}_{3 \mathrm{i}}\end{array}$ & $\begin{array}{c}\mathrm{i} \text {-type } \\
\text { interaction }\end{array}$ & $\begin{array}{c}(\mathrm{j}+\mathrm{l}) \text { type } \\
\text { interaction }\end{array}$ & $\begin{array}{c}\text { Epistasis } \times \\
\text { Replication }\end{array}$ & $\begin{array}{c}\mathrm{i} \text { type } \times \\
\text { Replication }\end{array}$ & $\begin{array}{c}\mathrm{j}+\mathrm{l}) \text { type } \\
\mathrm{x} \\
\text { replication }\end{array}$ \\
\hline Traits & df & 10 & 1 & 9 & 20 & 2 & \\
\hline $\begin{array}{l}\text { Marketable fruit yield } \\
\text { per plant }(\mathrm{g})\end{array}$ & & $97191.52^{* *}$ & $21427.84^{* *}$ & $\begin{array}{c}105609.71^{*} \\
*\end{array}$ & 85.48 & 98.31 & 84.06 \\
\hline $\begin{array}{l}\text { Days to 50\% } \\
\text { flowering }\end{array}$ & $191.23^{* *}$ & $163.70^{* *}$ & $210.84^{* *}$ & 16.93 & 31.60 & 15.30 \\
\hline Days to first picking & & $297.36^{* *}$ & $136.78^{* *}$ & 97.36 & 7.30 & 2.80 & 7.80 \\
\hline $\begin{array}{l}\text { Number of marketable } \\
\text { fruits per plant }\end{array}$ & $152.73^{* *}$ & $794.33^{* *}$ & $181.44^{* *}$ & 30.76 & 13.48 & 32.68 \\
\hline Fruit length $(\mathrm{cm})$ & & $54.61^{* *}$ & 15.46 & $52.30^{* *}$ & 16.23 & 13.10 & 16.58 \\
\hline Fruit diameter $(\mathrm{cm})$ & & $14.86^{* *}$ & 0.179 & $16.49^{* *}$ & 1.05 & 2.37 & 0.91 \\
\hline
\end{tabular}

*,** Significant @ 5\% and 1\% level

Table.3 Estimates of additive and dominance components, degree of dominance, correlation coefficient (sums and differences) and heritability for yield and its component traits in brinjal

\begin{tabular}{|l|c|c|c|c|c|c|}
\hline & \multicolumn{6}{|c|}{ Estimates of genetic parameters } \\
\hline Source of variation & $\mathrm{D}$ & $\mathrm{H}$ & $(\mathrm{H} / \mathrm{D})^{1 / 2}$ & $\mathrm{r}$ & $\mathrm{F}$ & $\begin{array}{l}\text { Heritability } \\
\text { (n.s) }\end{array}$ \\
\hline $\begin{array}{l}\text { Marketable fruit yield per } \\
\text { plant (g) }\end{array}$ & $20421.11^{* *}$ & $51144.29^{* *}$ & 1.58 & $0.25^{* *}$ & $-12722.14^{* *}$ & -0.43 \\
\hline Days to 50 \% flowering & $422.21^{* *}$ & $151.62^{* *}$ & 0.59 & $0.15^{* *}$ & $-18.68^{* *}$ & 10.52 \\
\hline Days to first picking & $473.79^{* *}$ & $119.65^{* *}$ & 0.50 & 0.30 & -35.53 & 12.26 \\
\hline $\begin{array}{l}\text { Number of marketable fruits } \\
\text { per plant }\end{array}$ & $21.02^{*}$ & $66.05^{* *}$ & 1.77 & 0.48 & -2.67 & 8.16 \\
\hline Fruit length (cm) & $23.06^{* *}$ & $45.29^{* *}$ & 1.40 & -0.39 & 5.53 & 0.18 \\
\hline Fruit diameter $(\mathrm{cm})$ & $5.03^{*}$ & 6.32 & 1.12 & -0.30 & 0.71 & -1.68 \\
\hline
\end{tabular}

*,** Significant @ 5\% and 1\% level 
The present study revealed (i) type epistasis was significant for all traits except fruit length and fruit diameter and whereas for $(j+1)$ type epistasis was significant for all traits except days to first picking. Deshmukh et al., (2014) suggested that non-additive interactions are more important for components of yield rather than plant characteristics. Since $(j+1)$ type epistasis is more useful for hybrid development therefore hybrid breeding can be a viable approach for brinjal improvement.

Additive component was significant for all the traits whereas dominance component was significant for all traits except fruit diameter. The preponderance of additive component for expression of fruit yield and other traits indicate the amenability of these traits to improvement through simple selection procedure. But one of the important implications of existence of substantial amount of epistatic component is that selection procedure shall not be fruitful in immediate progenies and process has to be delayed to later generations when appreciable homozygosity is achieved. Recurrent selection procedures may be useful in the sense that it will exploit both additive and non-additive components of genetic variation for bringing about improvement in fruit yield and its related attributes. Such a strategy will help increase frequency of favourable alleles while maintaining genetic variation in breeding population (Doerksen et al., 2003). In fact reciprocal recurrent selection sets in favourable changes in the population performances and is designed to make use of both additive and non-additive components. The perusal of Table 3 reveals non-significant correlation coefficients due to sums and differences, which depict the direction of dominance. Thus positive and negative genes are equally distributed among the parents used in the present study. Since epistasis was detected for most of the traits, it is hereby inferred that estimation of genetic components of variation by models assuming absence of epistasis would be significantly biased and can cause consequent bias in estimates of heritability and other genetic parameters. However, as of now, there is no conclusive evidence about the extent of bias and the effect of epistasis on the expression of quantitative traits. Studies for assessment of relative importance of epistatic component need to be carried out by developing appropriate genetic modes.

For the inheritance of different characters the triple test cross exhibited that the additive, dominance and epistasis gene actions were important. In early segregating generations biparental mating as well as mating of selected plants could be attempted for developing potential populations having optimum levels of homozygosity and heterozygosity. Although, transgressive segregants can be isolated by alternative intermating and subsequent handling of segregating generations in order to obtain high yielding stable lines in brinjal where all the three kinds of gene effects are present.

\section{Acknowledgement}

The author is highly grateful to Dr. K.S. Chandel (Professor) for his help in development of test cross progenies at Vegeatble farm, Palampur (H.P.), India.

\section{References}

Bhateria, S., Sood, S.P. and Pathania, A. 2006. Genetic analysis of quantitative traits across environments in linseed (Linum usitatissimum L.). Euphytica, 150: 185-194.

Chahal, G.S. and Jinks, J.L. 1978. A general method of detecting the additive, dominance and epistatic variation that inbred lives can generate using single tester. Heredity. 40: 117-125. 
Chaudhary, D.R. 1999. Components of genetic variation in yield traits of brinjal (Solanum melongenaL.). Himachal Journal of Agricultural Research, 25 (1/2): 43-47.

Chauhan, A. and Chandel, K.S. 2016. Genetic analysis of biparental progenies in eggplant, Solanum melongena L. International Journal of Farm Sciences, 6(2): 84-96.

Dagade, S.B., Dhaduk, L.K., Mehata, D.R. and Barad, A.V. 2015. Genetic architecture of some yield and biochemical traits of tomato Solanum lycopersicum L. Electronic Journal of Plant Breeding. 6 (3): 787-791.

Deshmukh, S.B., Sawant, S.N., Narkhede, G.W. and Dod, V.N. 2014. Gene Action Studies in Brinjal (Solanum melongena). Middle-East Journal of Scientific Research. 21(11): 2177-2181.

Doerksen, T., Kannenberg, L. and Lee, L. 2003. Effect of recurrent selection on combining ability in maize breeding populations. Crop Sci. 43: 1652-1658.

Hazra, P., Chattopadhyay, A., Karmakar, K. and Dutta, S. 2011. Brinjal In: Modern Technology in Vegetable Production. New India Publishing Agency, New Delhi. pp. $103-114$.

Kaur, A. and Thakur, J.C. 2007. Genetic studies in brinjal through biparental mating. Haryana Journal of horticultural Science. 36(3and4): 331-333.

Kearsey, M.J. and Jinks, J.L. 1968. A general method for detecting additive, dominance and epistatic variation for metrical traits. Heredity. 23: 403-409.

Ketata, H., Smith, E.L., Edwards, L.H. and McNew, R.W. 1976. Detection of epistatic, additive and dominance variation in winter wheat. Crop Sci. 16: $1-4$.

Nath, P., Velayudhan, S. and Singh, D.P. 1987. Vegetable for the Tropical Region. Indian Council of Agricultural Research, New Delhi, pp 23-24.

Reddy, E.E.P. and Patel, A.I. 2014. Studies on gene action and combining ability for yield and other quantitative traits in brinjal (Solanum melongena L.). Trends in Biosciences 7(5): 381-383.

Sabolu, S., Keshubhai, B.K., Chintan, R.M. and Kumar, S. 2014. Generation mean analysis of fruit quality traits in eggplant (Solanum melongena L.). African Journal of Crop Science 8(2): 243-250.

Salehuzzaman, M. and Alam, M.S. 1983. Genetic analysis of yield and its components in the eggplant. SABRAO Journal. 15(1): 11-15.

Singh, J.P. and Singh, K.P. 2010. Modified triple test cross analysis for yield and its component in tomato (Licopersican esculentum MILL.). Veg. Sci. 37(1): 102-104.

Zeven, A.C. and Zhukovsky, P.M. 1975. Dictionary of cultivated plants and their centres of diversity. Wageningen, Netherlands. 219p.

\section{How to cite this article:}

Smita Kumari, K.S. Chandel and Aanchal Chauhan. 2017. Triple Test Cross Analysis for Yield and Horticultural Traits in Brinjal (Solanum melongena L.). Int.J.Curr.Microbiol.App.Sci. 6(6): 2807-2812. doi: https://doi.org/10.20546/ijcmas.2017.606.334 